\title{
Syndecan-1 Laktat dan Profil Lipid sebagai Faktor Risiko Keparahan dan Mortalitas Sepsis
}

\author{
Yopie Wiguna, ${ }^{1}$ Philia Setiawan, ${ }^{1}$ Bambang Pujo semedi, ${ }^{1}$ Bambang Purwanto ${ }^{2}$ \\ ${ }^{1}$ Departemen Anestesiologi dan Reanimasi Fakultas Kedokteran Universitas Airlangga/RSUD \\ Dr. Soetomo Surabaya, ${ }^{2}$ Departemen Ilmu Faal/Fakultas Kedokteran Universitas Airlangga Kota \\ Surabaya
}

\begin{abstract}
Abstrak
Pada sepsis, endothelial glycocalyx (EG), dapat rusak dan luruh melepaskan syndecan-1 ke dalam plasma. Kerusakan EG akan mengganggu mikrosirkulasi, menimbulkan hipoperfusi jaringan, dan meningkatkan kadar laktat. Gangguan profil lipid pada sepsis terjadi karena gangguan metabolisme dan kerusakan langsung hepatosit akibat meluruhnya EG. Penelitian ini bermaksud menganalisis syndecan-1, laktat, dan profil lipid sebagai faktor risiko keparahan dan mortalitas pada pasien sepsis. Penelitian ini adalah penelitian analitik observasional pada 39 pasien dewasa yang memenuhi kritera sepsis-3. Keparahan sepsis diklasifikasikan menjadi sepsis dan syok septik dan ditentukan dalam 6 jam setelah time zero berdasarkan penggunaan vasopresor, kecukupan resusitasi cairan, dan nilai laktat ulangan. Kematian 7 hari dihitung sejak time zero sepsis. Syndecan-1, laktat, dan profil lipid diambil dalam jam pertama setelah time zero dianalisis sebagai faktor risiko keparahan dan mortalitas 7 hari. Analisis data dilakukan dengan uji logistik regresi bivariat dan multivariat. Pada penelitian ini didapatkan 20 pasien dengan sepsis, 19 pasien dengan syok septik. Berdasar atas mortalitas 7 hari, 10 pasien meninggal dan 29 pasien bertahan hidup. Laktat dan syndecan-1 merupakan prediktor keparahan pada sepsis. Laktat merupakan variabel yang lebih superior dibanding dengan syndecan-1 sebagai prediktor keparahan sepsis. Laktat merupakan prediktor untuk mortalitas 7 hari pada pasien sepsis. Simpulan penelitian ini adalah laktat dan syndecan-1 merupakan prediktor keparahan pada sepsis. Laktat merupakan prediktor kematian 7 hari pada sepsis.
\end{abstract}

Kata kunci: Keparahan sepsis, laktat, mortalitas 7 hari, profil lipid, sepsis, syndecan-1

\section{Syndecan-1 Lactate and Lipid Profiles as Risk Factors for Severity and Mortality in Sepsis}

\begin{abstract}
In sepsis, endothelial glycocalyx (EG) may experience damages and decay, releasing syndecan-1 into plasma. EG damages will disrupt microcirculation, causing tissue hypoperfusion and increasing lactate levels. Disorders of the lipid profile in sepsis occur due to metabolic disorders and direct hepatocyte damages due to EG shedding. This study intended to analyze the Syndecan-1, lactate, and lipid profiles as risk factors for severity and mortality in septic patients. This was an observational analytic study on 39 adult patients who met the criteria for sepsis-3. Sepsis severity was classified into sepsis and septic shock and was determined within 6 hours after time zero based on the vasopressor use, adequacy of fluid resuscitation, and repeat lactate values. The 7-day mortality was counted from time zero sepsis. Syndecan-1, Lactate, and Lipid Profiles were assessed within the first hour after time zero and analyzed as risk factors for severity and 7-day mortality. Data analysis was performed using bivariate and multivariate logistic regression tests. In this study, there were 20 patients with sepsis, 19 patients with septic shock. Based on the 7-day mortality, 10 patients died and 29 patients survived. Lactate and Syndecan-1 are predictors of severity in sepsis. Lactate is superior than Syndecan-1 as a predictor of sepsis severity and is a predictor of 7-day mortality in septic patients. Nonetheless, both lactate and Syndecan-1 are predictors of severity in sepsis.
\end{abstract}

Keywords: Lactate, lipid profile, sepsis, severity of sepsis, syndecan-1, 7 days mortality

Korespondensi: Yopie Wiguna, dr., Departemen Anestesi dan Terapi Intensif Fakultas Kedokteran Universitas Airlangga RSUD Dr Soetomo Surabaya, Jl, Jl. Mayjen Prof. Dr. Moestopo No.6-8, Airlangga, Kec. Gubeng, Kota SBY, Jawa Timur 60286 Tlp (031) 5501078, Email yopiewiguna87@gmail.com 


\section{Pendahuluan}

Sepsis adalah disfungsi organ mengancam nyawa yang disebabkan oleh disregulasi respons tubuh inang terhadap infeksi. Diperkirakan 30 juta orang mengalami sepsis dan 5,3 juta orang meninggal karena sepsis di seluruh dunia setiap tahun. ${ }^{1}$ Hipotensi dan kegagalan organ merupakan penyebab mortalitas. ${ }^{2}$ Patofisiologi kegagalan organ disumbang oleh kerusakan endotelium vaskular. $^{3}$

Endothelial glikokaliks (EG) adalah lapisan pada sisi luminal pembuluh darah yang tersusun dari glycosaminoglycans (syndecan, glypican, hyaluronan) dan protein plasma termasuk albumin. EG berfungsi mencegah stres mekanik akibat aliran darah serta memproduksi nitrit oksida (NO), enzim protektif pembuluh darah (superoxida dismutase) dan faktor-faktor antikoagulan (antitrombin, protein C). Kerusakan jaringan pada sepsis akan menyebabkan degradasi EG dan peluruhan syndecan-1. Produk peluruhan EG bertindak sebagai damage associated molecular patterns (DAMPs) dan memicu kaskade inflamasi pada sepsis yang menyebabkan kebocoran kapiler, agregasi platelet, koagulasi, dan tonus vaskular hilang. Secara sistemik, hal ini menyebabkan gangguan perfusi dan oksigenasi jaringan serta menimbulkan gambaran klinis sepsis, yaitu edema, hipovolemia intravaskular, hipotensi, dan syok. ${ }^{4,5}$

Gangguan perfusi dan oksigenasi pada sepsis dinilai menggunakan kadar laktat. Hiperlaktatemia berasal dari peningkatan produksi laktat oleh jaringan tubuh akibat glikolisis aerobikdananaerobik dan penurunan klirens laktat. Hiperlaktatemia merupakan tanda bahaya. Panduan terapi seperti surviving sepsis campaign menggunakan laktat sebagai parameter untuk memulai dan mengevaluasi resusitasi cairan. ${ }^{6}$ Penelitian oleh Ostrowski dkk. $^{7}$ pada pasien sepsis menunjukkan hubungan bermakna antara syndecan-1 dan kadar laktat pada pasien sepsis. Hal ini menunjukkan hubungan yang erat gangguan EG dan gangguan perfusi dengan oksigenasi pada pasien sepsis.

Pasien dengan sepsis dapat mengalami gangguan profil lipid di antaranya kadar high-density lipoprotein (HDL), low-density lipoprotein (LDL) yang rendah, dan kadar trigliserida (TG) yang tinggi. ${ }^{8,9}$ Peran lipoprotein pada sepsis banyak diteliti dan menunjukkan hubungan yang erat dengan patofisiologi sepsis. HDL dan LDL merupakan prediktor yang baik sebanding dengan laktat terhadap kejadian gagal organ dan kematian pada sepsis. ${ }^{8}$ Studi pada pasien nonsepsis mendapatkan bahwa kadar Syndecan-1 dipengaruhi salah satunya oleh kadar trigliserida yang tinggi. ${ }^{10}$ Perubahan kadar Syndecan-1 dan hubungannya terhadap dislipidemia telah diteliti pada berbagai macam kondisi patologis seperti aterosklerosis, ${ }^{11}$ pascatransplantasi renal, ${ }^{12}$ dan fatty liver disease. ${ }^{13}$ Pada kondisi sepsis sangat mungkin terdapat korelasi syndecan-1 dengan dyslipidemia, namun hal ini belum pernah diteliti.

Uniknya peran EG dalam sepsis, menjadikan syndecan-1 menarik untuk diteliti sebagai penanda prognostik pada sepsis dan membandingkannya dengan penanda lain seperti laktat dan profil lipid. Penelitian ini bertujuan menganalisis hubungan kadar syndecan-1 (produk degradasi EG), laktat, dan profil lipid sebagai faktor risiko dengan keparahan dan mortalitas pasien sepsis.

\section{Subjek dan Metode}

Penelitian ini merupakan penelitian observasional analitik dengan desain prospektif, di ruang perawatan intensif RSUD dr Soetomo yang dilaksanakan pada bulan April 2020 hingga Juli 2020 yang telah mendapatkan persetujuan dari Komite Etik Rumah Sakit (No. 1904/KEPK/III/2020). Subjek penelitian ini adalah pasien sepsis yang berusia di atas 18 tahun, memenuhi kriteria The Third International Consensus Definitions for Sepsis and Septic Shock 2016 (Sepsis-3) yang dirawat di unit perawatan intensif RSUD dr Soetomo Surabaya. Pasien/ wali pasien bersedia menandatangani 
persetujuan (informed consent). Kriteria eksklusi pada penelitian ini adalah pasien dengan riwayat dislipidemia atau pernah mendapat pengobatan dislipidemia golongan statin atau nonstatin, dan periode 1 jam sesudah time zero sepsis telah terlampaui saat dilakukan pengambilan sampel darah dan kultur. Kriteria pengeluaran adalah pasien yang tidak dapat dilakukan pengambilan spesimen darah, dahak, atau bahan biakan lain untuk pemeriksaan kultur. Time zero sepsis didefinisikan sebagai waktu dokumentasi yang sesuai dengan elemen sepsis, yaitu tanda infeksi dan kegagalan organ. Teknik pengumpulan sampel penelitian menggunakan teknik total sampling. Semua subjek penelitian mendapatkan perlakuan yang sama dan tidak dilakukan alokasi kelompok. Besar sampel penelitian dihitung menggunakan rumus sampel untuk uji Cohort/studi longitudinal dan didapatkan besar sampel penelitian minimal sejumlah 39 pasien.

Data awal seperti usia, jenis kelamin, berat dan tinggi badan, tanda vital, tanda infeksi, pengukuran nilai qSOFA dan SOFA dicatat dalam lembar pengumpulan data. Kemudian, sesuai dengan manajemen pasien sepsis, tiap-tiap subjek diambil sampel darah untuk pemeriksaan syndecan-1, laktat, dan kadar profil lipid dalam waktu satu jam setelah time zero. Hasil evaluasi klinis dicatat dalam lembar pengumpulan data dan selanjutnya dianalisis.

Distribusi data penelitian dilakukan uji normalitas data menggunakan Uji ShapiroWilk. Data dengan distribusi normal dianalisis menggunakan analisis varian, sedangkan data dengan distribusi tidak normal dianalisis menggunakan Uji Kruskal Wallis. Analisis bivariate logistic regression dilakukan terhadap karakteristik dan variabel keparahan dan mortalitas 7 hari sepsis. Variabel yang memiliki nilai $\mathrm{p}<0,25$ dari hasil analisis bivariate logistic regression dilanjutkan dengan analisis multivariate logistic regression. Analisis statistik dikerjakan dengan perangkat lunak statistical package and service solution (SPSS) v19.

\section{Hasil}

Penelitian melibatkan 39 pasien sepsis dewasa yang terbagi hampir merata antara laki-laki dan perempuan dengan dominasi pasien kelompok usia 45-74 tahun, diikuti kelompok usia 18-44 tahun dan kelompok usia $>75$ tahun dan mayoritas memiliki body mass index (BMI) normal (Tabel 1).

Kadar rerata syndecan-1 didapatkan tinggi, yaitu $563,97 \pm 297,34 \mathrm{ng} / \mathrm{mL}$. Kadar laktat pada jam pertama menunjukkan rerata 2,42 $\pm 1,55$ $\mathrm{mmol} / \mathrm{L}$. Rerata HDL pada penelitian ini adalah $27 \pm 11,84 \mathrm{mg} / \mathrm{dL}$. Rerata LDL adalah $67,13 \pm 24,98 \mathrm{mg} / \mathrm{dL}$. Rerata trigliserida pada penelitian ini adalah $150,05 \pm 72,84 \mathrm{mg} / \mathrm{dL}$. Hubungan antarvariabel dependen disajikan pada Tabel 2. Kelompok yang lebih parah (syok septik) mengalami kematian 7 hari yang lebih tinggi dibanding dengan kelompok yang lebih tidak parah (sepsis).

Keparahan sepsis dalam penelitian ini

Tabel 1 Karakteristik Usia, BMI, Nilai SOFA, dan APACHE II berdasar atas Tingkat Keparahan dan Mortalitas 7 Hari

\begin{tabular}{lcccc}
\hline Variabel & \multicolumn{2}{c}{ Keparahan } & \multicolumn{2}{c}{ Mortalitas 7 Hari } \\
& $\begin{array}{c}\text { Sepsis } \\
(\mathbf{n = 2 0})\end{array}$ & $\begin{array}{c}\text { Syok Sepsis } \\
(\mathbf{n = 1 9 )}\end{array}$ & $\begin{array}{c}\text { Hidup } \\
(\mathbf{n = 2 9})\end{array}$ & $\begin{array}{c}\text { Meninggal } \\
(\mathbf{n = 1 0})\end{array}$ \\
\hline Usia, (tahun) & $48,75 \pm 20,87$ & $53,26 \pm 11,85$ & $49 \pm 18,484$ & $56,6 \pm 10,56$ \\
BMI, (kg/m $\left.{ }^{2}\right)$ & $24,25+4,49$ & $24,16 \pm 2,61$ & $23,91 \pm 3,85$ & $25,06 \pm 3,01$ \\
SOFA & $4,45 \pm 1,88$ & $7,42 \pm 2,22$ & $5,45 \pm 2,47$ & $7,2 \pm 2,3$ \\
APACHE II & $17,85 \pm 7,77$ & $23,16 \pm 5,18$ & $19,48 \pm 7,39$ & $23,2 \pm 5,49$ \\
\hline
\end{tabular}

Keterangan: $\mathrm{BMI}=$ body mass index; $\mathrm{SOFA}=$ sequential organ failure assessment; $\mathrm{APACHE} \mathrm{II}=$ acute physiology, age and chronic health II score 
Tabel 2 Nilai Mean Variabel Penelitian

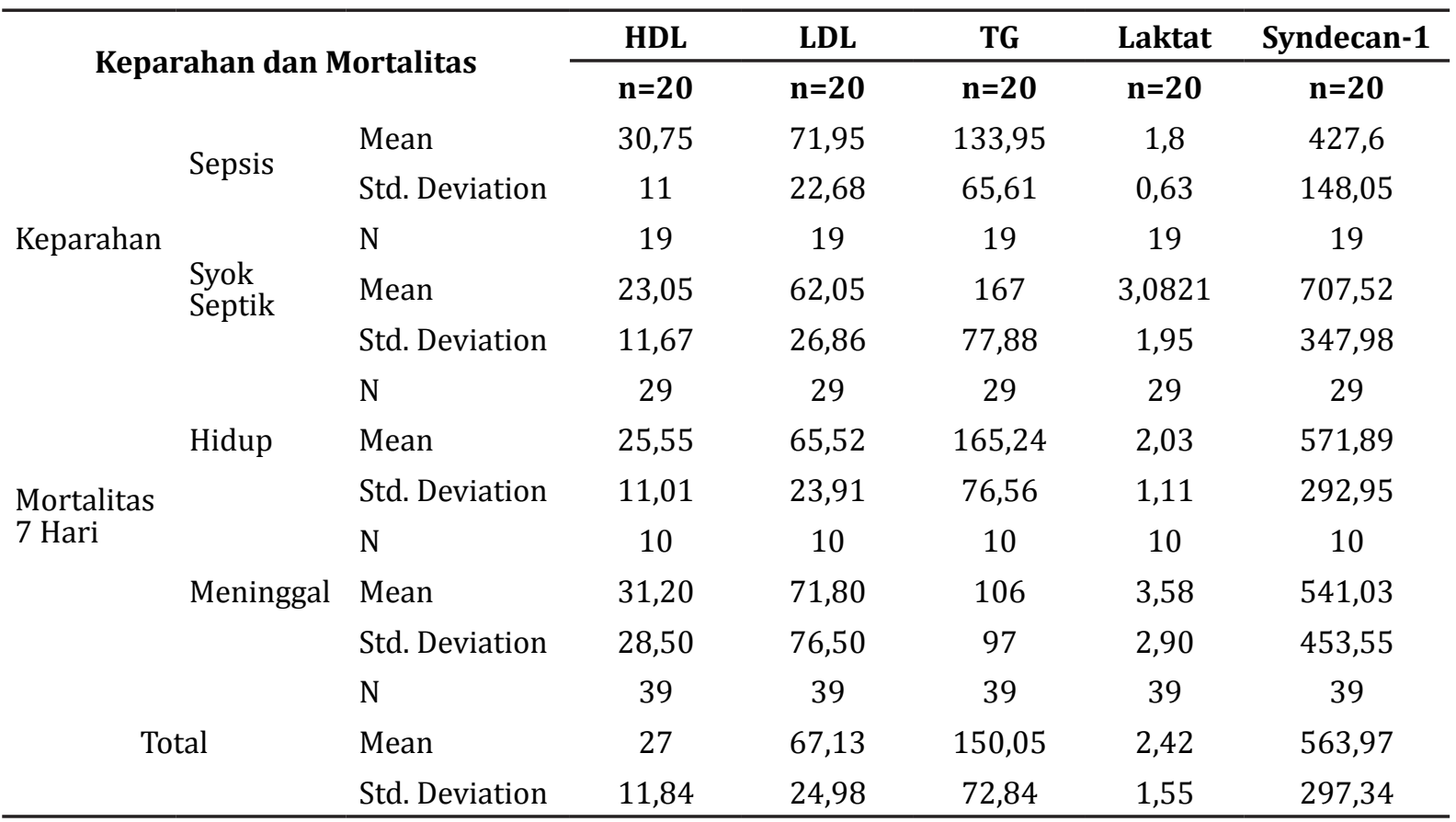

dibagi menjadi sepsis dan syok septik. Analisis bivariate logistic regression menunjukkan nilai SOFA, APACHE II, syndecan-1 dan laktat berkorelasi secara signifikan terhadap tingkat keparahan sepsis (Tabel 3).

Variabel yang memiliki nlai $\mathrm{p}<0,25$ dari hasil analisis bivariate logistic regression dilanjutkan dengan analisis multivariate logistic regression. Dari hasil analisis multivariate logistic regression didapatkan persamaan: Keparahan $(\mathrm{y})=-7,052+0,009$ syndecan $-1+1,280$ Laktat $-0,077$ HDL +

Tabel 3 Analisis Bivariate Logistic Regression Karakteristik dan Variabel Penelitian terhadap Keparahan Sepsis

\begin{tabular}{lccccc}
\hline \multirow{2}{*}{ Variabel } & \multirow{2}{*}{$\mathbf{B}$} & $\mathbf{p}$ & Exp (B) & \multicolumn{2}{c}{ 95\% C.I. EXP(B) } \\
\cline { 5 - 6 } & & & & Lower & Upper \\
\hline Jenis kelamin &, 318 &, 621 & 1,375 &, 388 & 4,867 \\
Usia, (tahun) &, 016 &, 405 & 1,016 &, 978 & 1,056 \\
BMI, (kg/m $\left.{ }^{2}\right)$ &,- 006 &, 942 &, 994 &, 835 & 1.183 \\
SOFA &, 732 &, 002 & 2,080 & 1,304 & 3,318 \\
APACHE II &, 125 &, 027 & 1,133 & 1,015 & 1,265 \\
Syndecan-1 &, 005 &, 014 & 1,005 & 1,001 & 1,009 \\
Laktat &, 781 &, 026 & 2,183 & 1,098 & 4,343 \\
HDL &,- 063 &, 051 &, 939 &, 882 & 1,000 \\
LDL &,- 017 &, 219 &, 983 &, 957 & 1,010 \\
TG &, 007 &, 163 & 1,007 &, 997 & 1,016 \\
\hline
\end{tabular}

Keterangan: Analisis menggunakan bivariat logistik regresi. Nilai $\mathrm{p}<0,05$ berarti signifikan secara statisitik. BMI $=$ body mass index; SOFA = sequential organ failure assessment; APACHE II = acute physiology, age and chronic health II score 
Tabel 4 Analisis Multivariate Logistic Regression Karakteristik dan Variabel Penelitian Terhadap Keparahan Sepsis

\begin{tabular}{lccccc}
\hline & \multirow{2}{*}{$\mathbf{B}$} & $\mathbf{p}$ & \multirow{2}{*}{$\mathbf{E x p ( B )}$} & \multicolumn{2}{c}{$\mathbf{9 5 \%}$ C.I. EXP(B) } \\
& & & & Lower & Upper \\
\hline Laktat & 1,280 &, 009 & 3,597 & 1,373 & 9,421 \\
Syndecan-1 &, 009 &, 018 & 1,009 & 1,002 & 1,016 \\
HDL &,- 077 &, 243 &, 926 &, 813 & 1,054 \\
LDL &, 017 &, 526 & 1,017 &, 965 & 1,072 \\
TG &, 001 &, 879 & 1,001 &, 985 & 1,018 \\
Constant & $-7,052$ &, 043 &, 001 & & \\
\hline
\end{tabular}

Keterangan: analisis menggunakan multivariat logistik regresi. Nilai $\mathrm{p}<0,05$ berarti signifikan secara statisitik

0,017 LDL + 0,001 TG. Laktat (RR 3,597 CI 95\% 1,373-9,421 p 0,009) merupakan variabel yang lebih superior dibanding dengan syndecan-1 (RR 1,009 CI 95\% 1,002-1,016 p $0,018)$ sebagai prediktor keparahan sepsis (Tabel 4).

Mortalitas sepsis pada penelitian ini diukur sebagai mortalitas 7 hari sejak awal perawatan di rumah sakit. Analisis bivariat dengan regresi logistik menunjukkan nilai laktat dan trigliserida berkorelasi secara signifikan terhadap mortalitas 7 hari sepsis (Tabel 5).

Variabel yang memiliki nilai $\mathrm{p}<0,25$ dari hasil analisis bivariate logistic regression dilanjutkan dengan analisis multivariate logistic regression. Dari hasil analisis multivariate logistic regressions. Variabel penelitian terhadap mortalitas 7 hari didapatkan persamaan: mortalitas 7 hari $(y)=$ $-2,109+0,031$ Usia + 0,862 Laktat + 0,032 HDL - 0,031 TG. Laktat (RR 2,369 CI 95\% 1,021 5,495 p 0,045) merupakan prediktor untuk mortalitas 7 hari pada pasien sepsis (Tabel 6).

\section{Pembahasan}

Penelitian ini mendapatkan bahwa rerata kadar syndecan-1 yang diambil pada jam pertama

Tabel 5 Analisis Bivariate Logistic Regression Karakteristik dan Variabel Penelitian Terhadap Mortalitas 7 Hari Sepsis

\begin{tabular}{lccccc}
\hline & \multirow{2}{*}{ B } & $\mathbf{p}$ & Exp(B) & \multicolumn{2}{c}{ 95\% C.I. EXP(B) } \\
\cline { 5 - 6 } & & & & Lower & Upper \\
\hline Jenis kelamin &, 336 &, 652 & 1,400 &, 325 & 6,027 \\
Usia &, 028 &, 227 & 1,029 &, 983 & 1,077 \\
BMI &, 087 &, 394 & 1,091 &, 893 & 1,332 \\
SOFA &, 297 &, 069 & 1,345 &, 977 & 1,851 \\
APACHE II &, 182 &, 158 & 1,083 &, 970 & 1,209 \\
Syndecan-1 &, 000 &, 775 & 1,000 &, 997 & 1,002 \\
Laktat &, 642 &, 018 & 1,900 & 1,117 & 3,230 \\
HDL &, 040 &, 198 & 1,041 &, 979 & 1,107 \\
LDL &, 010 &, 490 & 1,010 &, 981 & 1,040 \\
TG &,- 019 &, 044 &, 982 &, 964 & 1,000 \\
\hline
\end{tabular}

Keterangan: analisis menggunakan bivariat logistik regresi. Nilai $\mathrm{p}<0,05$ berarti signifikan secara statisitik. $\mathrm{BMI}=$ body mass index; $\mathrm{SOFA}=$ sequential organ failure assessment; $\mathrm{APACHE} \mathrm{II}=$ acute physiology, age and chronic health II score 
Tabel 6 Analisis Multivariate Logistic Regression Karakteristik dan Variabel Penelitian t erhadap Mortalitas 7 Hari Sepsis

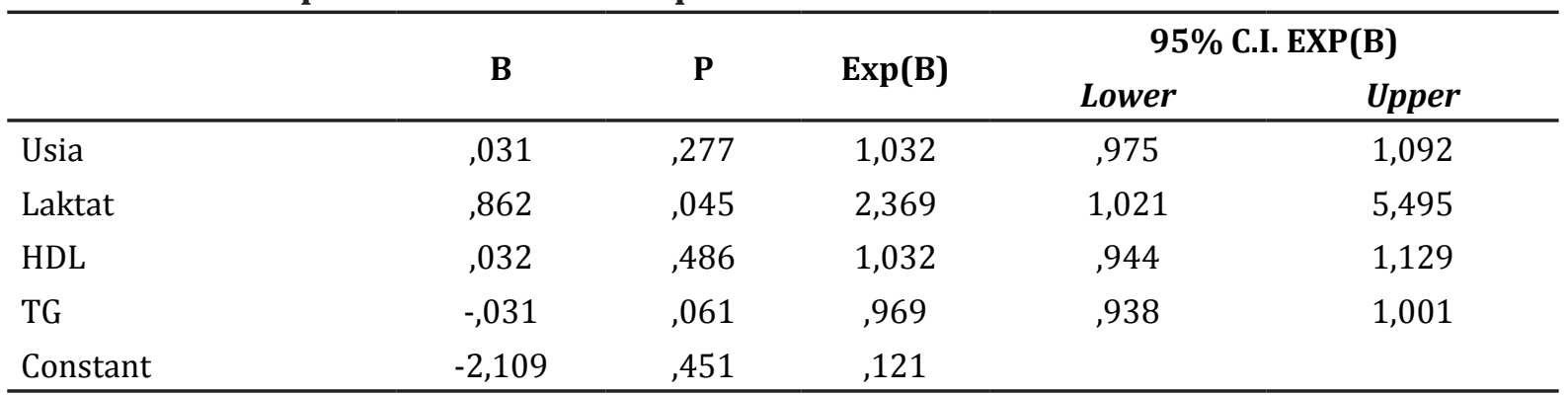

Keterangan: analisis menggunakan multivariat logistik regresi, Nilai $\mathrm{p}<0,05$ berarti signifikan secara statisitik

adalah $563,97 \mathrm{ng} / \mathrm{mL} \pm 297,34$. Hasil ini secara umum menunjukkan bahwa kadar syndecan-1 pada sampel penelitian ini memiliki rentang yang sesuai dengan pasien sepsis berat dan syok septik pada penelitian sebelumnya. Penelitian oleh Anand dkk. ${ }^{14}$ pada tahun 2016 dan menggunakan kriteria SSC tahun 2013 mendapatkan bahwa kadar syndecan-1 pada hari pertama pada subjek normal adalah 28,15 $\mathrm{ng} / \mathrm{mL}$, pada subjek sepsis berat $342,1 \mathrm{ng} / \mathrm{mL}$, dan pada syok septik 653,5 ng/mL. Hal ini menunjukkan bahwa pada pasien sepsis berat dapat terjadi peningkatan hingga 12 kali kadar syndecan 1 pada hari pertama dan pada pasien dengan syok septik peningkatannya dapat mencapai 25 kali lipat. ${ }^{14}$

Penelitian ini mendapatkan bahwa kadar laktat yang diambil pada jam pertama menunjukkan rerata 2,42 $\pm 1,55$. Hiperlaktatemia pada sepsis dikaitkan dengan luaran yang merugikan. Kematian meningkat secara linier di atas konsentrasi laktat sekitar $1 \mathrm{mmol} / \mathrm{L}$ dan kadar laktat di atas $4 \mathrm{mmol} / \mathrm{L}$ dikaitkan dengan kelangsungan hidup hanya $11 \%$ pada pasien sakit kritis di Unit Perawatan Intensif (ICU) setelah 24 jam: ambang batas tersebut merupakan penanda yang berguna untuk tingkat keparahan penyakit dengan risiko kematian yang lebih tinggi. ${ }^{15}$

Pada pasien sepsis yang menjadi sampel dalam penelitian ini didapatkan kadar HDL rerata yang rendah, yaitu $27,4 \pm 11,8 \mathrm{mg} /$ dL. Kadar trigliserida didapatkan cenderung tinggi dengan rerata $146,9 \pm 71,1 \mathrm{mg} / \mathrm{dL}$. Kadar
LDL didapatkan rerata $68,3 \pm 24,98 \mathrm{mg} / \mathrm{dL}$ yang tergolong rentang normal. Hasil yang didapatkan pada penelitian ini bersesuaian dengan beberapa penelitian lain yang mendapatkan pasien sepsis akan cenderung memiliki kadar HDL rendah dan trigliserida yang tinggi. ${ }^{8,16,17}$ Studi oleh Leuween dkk. ${ }^{18}$ pada tahun 2003 menunjukkan bahwa terdapat penurunan kadar HDL pada pasien sepsis berat.

Pada penelitian ini keparahan sepsis dibagi menjadi sepsis dan syok sepsis sesuai dengan kriteria sepsis. ${ }^{6}$ Analisis multivariat dengan regresi logistik menunjukkan -1 dan laktat berkorelasi secara signifikan terhadap tingkat keparahan sepsis.

Dari hasil analisis multivariate logistic regression didapatkan persamaan: Keparahan $(y)=-7,052+0,009$ syndecan $+1,280$ Laktat - 0,077 HDL + 0,017 LDL + 0,001 TG. Dari persamaan ini diketahui bahwa nilai laktat dan syndecan-1 dapat menjadi prediktor dengan pembobotan masing-masing 1,280 untuk laktat dan 0,009 untuk syndecan-1.

Penelitian ini serupa dengan penelitian yang dilakukan oleh Anand dkk. ${ }^{14}$ pada tahun 2016 yang membandingkan kadar syndecan-1 dan hialuronan pada subjek sehat, sepsis, severe sepsis, dan syok septik. Keparahan sepsis pada penelitian Anand dkk. ${ }^{14}$ diklasifikasikan berdasar atas kriteria surviving sepsis campaign tahun 2012. Kadar syndecan-1 pada hari pertama menunjukkan peningkatan seiring dengan peningkatan keparahan sepsis 
dari pasien sehat, sepsis, severe sepsis dan syok septik (secara berurutan adalah 28,15 $\mathrm{ng} / \mathrm{mL}, 85,78 \mathrm{ng} / \mathrm{mL}, 342,1 \mathrm{ng} / \mathrm{mL}, 653,5 \mathrm{ng} /$ $\mathrm{mL}$ ). Hasil penelitian ini serupa dengan hasil penelitian Anand dkk., cut-off yang didapatkan pada penelitian ini terletak di antara cut-off severe sepsis dan syok septik yang didapatkan pada penelitian Anand dkk.. Penelitian Anand dkk. masih menggunakan Sepsis-2 sebagai kriteria pembagian keparahan sepsis, sementara penelitian ini menggunakan kriteria dari Sepsis-3. ${ }^{14}$

Secara teoretis temuan ini dapat dijelaskan bahwa pada pasien dengan syok septik terjadi kerusakan lapisan EG yang lebih luas yang berdampak pada kegagalan organ yang lebih berat. ${ }^{19}$ Chelazzi dkk. ${ }^{19}$ menjelaskan pada sepsis EG terpapar mediator pro-inflamasi seperti interleukin, bradykinin, thrombin, growth factor, dan histamine. Mediatormediator ini mempromosikan rolling, adhesi dan migrasi leukosit yang menginisiasi kerusakan dan inflamasi pada endotel dan jaringan. Kerusakan lapisan EG ini tercermin pada kadar syndecan-1 yang lebih tinggi pada pasien yang mengalami syok septik karena pasien syok septik memiliki derajat inflamasi yang lebih berat. ${ }^{13}$

Dalam penelitian ini ini tidak didapatkan hubungan antara profil lipid (HDL, LDL, trigliserida) dan keparahan sepsis. Penelitian-penelitian sebelumnya banyak membandingkan profil lipid sebagai prediktor mortalitas, namun belum didapatkan penelitian yang berupaya menganalisis profil lipid sebagai faktor risiko keparahan pada sepsis.

Dari hasil analisis multivariate logistic regression, variabel penelitian terhadap mortalitas 7 hari didapatkan persamaan: mortalitas 7 hari $(y)=-2,109+0,031$ Usia $+0,862$ Laktat $+0,032$ HDL - 0,031 TG. Dari persamaan ini usia, laktat, HDL, dan TG merupakan faktor risiko mortalitas sepsis. Dari variabel tersebut yang paling berpengaruh terhadap mortalitas 7 hari pada pasien sepsis adalah laktat.

Hasil yang didapatkan pada penelitian ini sesuai dengan hasil pada penelitian terdahulu.
Penelitian oleh Mikkelsen dkk. ${ }^{20}$ pada tahun 2009 yang membagi kadar laktat menjadi low ( $\leq 2 \mathrm{mmol} / \mathrm{L})$, intermediate $(2-3,9 \mathrm{mmol} / \mathrm{L})$, dan high ( $\geq 4 \mathrm{mmol} / \mathrm{L})$ mendapatkan bahwa nilai inisial laktat serum lebih tinggi pada pasien yang mengalami kegagalan organ berat, yang ditunjukkan oleh skor APACHE II yang lebih tinggi. Kadar laktat tinggi diketahui merupakan prediktor mortalitas pada pasien sepsis. Penelitian oleh Song dkk. ${ }^{21}$ pada tahun 2016 pada 436 pasien dengan syok septik mendapatkan bahwa kadar laktat tinggi dan glomerular filtration rate merupakan faktor risiko mortalitas pada pasien syok septik. Laktat yang tinggi menghasilkan odds ratio (OR) 1,286 untuk mortalitas 7 hari dan RR 1,346 untuk mortalitas 28 hari.

Asidosis laktat pada sepsis dan syok septik terjadi sebagai akibat dari hipoksia jaringan karena pengiriman oksigen gagal untuk memenuhi kebutuhan oksigen seluruh tubuh, di sisi lain hal ini juga diperberat dengan metabolism meningkat pada pasien sepsis. Resusitasi dini dengan koreksi volume, tekanan darah dan saturasi jaringan oksigen, mengurangi kematian akibat syok septik dari $60 \%$ menjadi $20 \%{ }^{22}$ Hasil ini menunjukkan bahwa, pada fase resusitasi awal syok septik, produksi asidosis laktat terutama berasal dari metabolisme anaerobik. Pada syok septik yang berkepanjangan, asidosis laktat dapat dijelaskan dengan ekstraksi oksigen jaringan yang terganggu karena disfungsi mikrosirkulasi sekunder dan proses inflamasi. Pada sepsis, rasio ekstraksi oksigen dapat turun sampai $50 \%$ atau kurang sehingga pembentukan asam laktat meningkat. Pada pasien dengan sepsis yang stabil secara hemodinamik, hiperlaktatemia mungkin terjadi akibat gangguan klirens laktat dibanding dengan kelebihan produksi, yaitu pada pasien dengan disfungsi hati yang sudah ada sebelumnya atau akibat pembersihan laktat.

Pada penelitian ini tidak didapatkan hubungan yang bermakna antara syndecan-1 dan mortalitas 7 hari pada pasien sepsis. Hasil yang didapatkan pada penelitian ini berbeda dengan penelitian oleh Anand dkk. ${ }^{14}$ pada 
tahun 2016. Anand dkk. ${ }^{14}$ mendapatkan kadar syndecan-1 pada hari pertama secara signifikan lebih tinggi pada pasien sepsis yang meninggal dibanding dengan pasien yang bertahan hidup (412,3 ng/mL vs 782,3 ng/mL). Penelitian ini mendapatkan bahwa kadar syndecan-1 pada kelompok yang meninggal tidak berbeda dibandingkan kelompok yang bertahan hidup. Perbedaan hasil ini mungkin disebabkan oleh perbedaan metodologi, pada penelitian Anand dkk., kadar syndecan-1 diukur secara berkala dan mortalitas dinyatakan sebagai mortalitas selama perawatan di rumah sakit.

Penelitian ini tidak mendapatkan hubungan yang bermakna antara profil lipid (HDL, LDL, trigliserida) dan mortalitas 7 hari pada pasien sepsis. Penelitian oleh Chien dkk. ${ }^{16}$ pada tahun 2005 mendapatkan bahwa kadar HDL yang rendah pada hari pertama sepsis berhubungan dengan peningkatan mortalitas dan keparahan klinis pasien. Subjek penelitian dengan kadar HDL $<20 \mathrm{mg} / \mathrm{dL}$ memiliki mortalitas 30 hari yang lebih tinggi dibanding dengan subjek penelitian yang memiliki kadar HDL $\geq 20 \mathrm{mg} / \mathrm{dL}$. Selain itu, lama tinggal di ICU dan kejadian infeksi yang didapatkan di rumah sakit (nosokomial) meningkat pada pasien dengan kadar HDL lebih rendah. Penelitian lain oleh Lee dkk. pada tahun 2015 terhadap 117 pasien dengan sepsis dan syok septik mendapatkan kadar trigliserida dan nilai SOFA berhubungan dengan mortalitas hari pertama. Sementara kadar trigliserida, LDL, dan Apo A-1 berbeda bermakna secara linier dengan keparahan sepsis sesuai dengan kriteria sepsis, severe sepsis, dan syok septik. Perbedaan hasil ini mungkin disebabkan oleh perbedaan metodologi dan karakteristik sampel pengukuran profil lipid dilakukan secara serial setiap 2 hari.

\section{Simpulan}

Kadar syndecan-1 merupakan prediktor keparahan, namun bukan merupakan prediktor mortalitas 7 hari pada pasien sepsis. Kadar laktat merupakan prediktor keparahan dan mortalitas 7 hari pada pasien sepsis. Profil lipid (HDL, LDL, trigliserida) bukan merupakan prediktor keparahan dan mortalitas 7 hari pada pasien sepsis.

\section{Daftar Pustaka}

1. Fleischmann C, Scherag A, Adhikari N, Hartog C, Tsaganos T, Schlattmann P, dkk. Assessment of global incedencce and mortality of hospital-treated sepsis. Current estimates and limitations. Am J Respirat Crit Care Med. 2016;193(3):25972.

2. Vincent J, Nelson D, WIlliams M. Is worsening multiple organ failure the cause of death in patient with severes sepsis in the United States. Crit Care Med. 2011;39:1050-5.

3. Coletta C, Modis K, Olah G, Brunyanszki A, Herzig D, Sherwood E. Endothelial dysfunction is a potential contributor to multiple organ failure and mortality in aged mice subjected to septic shock: preclinical studies in a murine model of cecal ligation and puncture. Crit Care. 2014;18:511-3.

4. Chappell D, Jacob M. Role of the glycocalyx in fluid management: small things matter. Best Pract Res Clin Anaesthesiol. 2014;28:227-34.

5. Woodcock T, Woodcock T. The revised starling equation and the glycocalyx model of transvascular fluid exchange: an impeoved paradigm for prescribing intravenous fluid therapy. $\mathrm{Br} \mathrm{J}$ Anaesth. 2012;108:384-94.

6. Rhodes A, Evans L. Surviving Sepsis Campaign: International Guidelines for Management of Septic and Septic Shock: 2016. Crit Care Med. 2017;45(3):1-67.

7. Ostrowski S, Berg R, Windelov N, Meyer M, Plovsing R, Moller K, dkk. Coagulopathy, cathecolamines, and biomarkers of endothelial damage in experimental human endotoxemia and in patients with severe sepsis: a prospective study. J Crit Care. 2013;28(5):586-96.

8. Cirstea M, Wailey K, Russell J, Brunham L, Genga K, Boyd J. Decreased high-density lipoprotein cholesterol level is an early 
prognostic marker for organ dysfunction and death in patients with suspected sepsis. J Crit Care. 2017;38:289-94.

9. Zou G, He J, Ren B, Xu F, Xu G, Zhang W. The delta high-density lipoprotein cholesterol ratio; a novel parameter for gram negative sepsis. Springer Plus. 2016;1044(5):1-12.

10. Oda K, Okada Hikeshi, Suzuki A, Tomita Hiroyuki. Factors enhancing serum syndcan-1 concentrations: a large comprehensive medical examination. J Clin Med. 2019;8:1320-30.

11. Tojo MY. Vaskular endothelial glycocalyx as a mechanism of vascular endothelial dysfunction and atherosclerosis. World J Cardiovasc Dis. 2020;10(10):1-19.

12. Adepu S, Katta K, Tietge U, Kwakernaak ADW, van Goor H, Navis G. Hepatic syndecan-1 changes associate with dyslipidemia after renal transplantation. Am J Transplantation. 2014;14(10):232838.

13. Yilmaz Y, Eren F, Colak Y, Senates E, Celikel C, Imeryuz N. Hepatic expression and serum levels of syndecan-1 in patients with nonalcoholic fatty liver disease. Scandinavian J Gastroenterol. 2012;47(12):611-6.

14. Anand D, Ray S, Srivastava L, Bhargava S. Evolution of serum hyaluronan and syndecan levels in prognosis of sepsis patients. Clin Biochemical. 2016;49:76876.

15. Jones A. Should lactate clearacne be substituted for central venous oxygen saturation as goals of early severe sepsis and septic shock therapy?. Chest. 2011;140:1406-8.
16. Chien JY, Jerng JS, Yu CJ, Yang PC. Low serum level of high-density lipoprotein cholesterol is a poor prognostic factoir for severe sepsis. Crit Care Med. 2005;33(8):1688-93.

17. Pazzini A, Kurz K, Orth-Hoeller D, FIlle M, Lunger L, Tancevski I. The impact of bacteremia on lipoprotein concentrations and patient's outcome: a retrospective analysis. J Clin Microbiol Infect Dis. 2019;2019:1-8.

18. Leeuwen H, Heezius E, Dallinga G, Strijp J, Verhoef J, Kessel K. Lipoprotein metabolism in patients with severe sepsis. Crit Care Med. 2003;31(5):1359-66.

19. Chelazzi C, Villa G, Mancinelli P, De Gaudio AR, Adembri C. Glycocalyx and sepsis-induced alterations in vascular permeability. Crit Care. 2015;19:1-7.

20. Mikkelsen ME, Miltiades AN, Gaieski DF, Goyal M, Fuchs BD, Shah CV, dkk. Serum lactate is associated with mortality in severe sepsis independent of organ failure and shock. Crit Care Med. 2009;37(5):1670-6.

21. Song JE, Kim MH, Jeong WY, Jung IY, Oh DH, Kim YC, dkk. Mortality risk factors for patients with septic shock afer implementation of the surviving sepsis campaign bundles. Infect Chemother. 2016;48(3):199-208.

22. Yealy D, Kellum J. ProCESS: a randomized trial of protocol based care for early septic shock. New Engl J Med. 2014;370:168393.

23. Lee SH, Park MS, Park BH, Jung WJ. Prognostic implications of serum lipid metabolism over time during sepsis. Biomed Res Internat. 2015;2015:1-8. 